\title{
Scanning and transmission electron microscopy of the histopathological impact of Macrogyrodactylus clarii (Monogenea: Gyrodactylidae) on the gills of catfish, Clarias gariepinus
}

\author{
Mohammed Mohammed El-Naggar ${ }^{1,2}$, Joanne Cable ${ }^{2}$, Safaa Zaky Arafa ${ }^{1,3}$, Samir Ahmed El-Abbassy ${ }^{1}$ and \\ Graham C. Kearn ${ }^{4}$
}

\author{
${ }^{1}$ Zoology Department, Faculty of Science, Mansoura University, Mansoura, Egypt; \\ ${ }^{2}$ School of Biosciences, Cardiff University, UK; \\ ${ }^{3}$ Biology Department, College of Medicine, University of Dammam, Kingdom of Saudi Arabia; \\ ${ }^{4}$ School of Biological Sciences, University of East Anglia, Norwich, UK
}

\begin{abstract}
Scanning and transmission electron microscopy (TEM) were used to study the histopathological effects of the monogenean Macrogyrodactylus clarii Gussev, 1961 on the gills of the catfish Clarias gariepinus (Burchell). Suction generated during attachment created 'footprints' on host surfaces in which the host tissues were elevated above the general gill surface. 'Footprints' were bordered by four clefts caused by the muscular flaps on the anterior, lateral and posterior margins of the haptor. The hamuli points penetrate the gill tissue but no evidence was found for the insertion of the marginal hooklets. At the site of attachment, host cells adjacent to the lateral flaps often appeared compressed and widely spaced with large intercellular spaces. Desquamation of these surface epithelia was also apparent and some of the widely spaced epithelial cells had pseudopodium-like processes. Cells within the upper surface epithelial layer of the host were vacuolated and necrotic. Ruptured blood capillaries (blood spaces) in the secondary gill lamellae contained atypical compressed erythrocytes, agranular and granular leucocytes and evidence of haemorrhaging. Cells with fibrotic cytoplasm, putative phagocytes and host mucous cells were evidence of a host response at the site of parasite attachment. The possible role of these cells is discussed in relation to host resistance against infection.
\end{abstract}

Keywords: ultrastructure, histopathology, fish disease, aquatic health, monogeneans

The catfish Clarias gariepinus (Burchell) is considered to be one of the most important freshwater fishes in Africa (Bishai and Khalil 1997). In Egypt, it represents a cheap source of animal protein for a high proportion of the human population. Also, it is a major warm water aquaculture species in Africa and Asia and has been introduced to Europe and Latin America (FAO 1997, Ali 2001). Moreover, it is a suitable alternative to tilapia for subsistence fish farming in Africa; catfish yields from ponds can be $2.5 \times$ higher than those of tilapia (Hogendoorm 1983). However, C. gariepinus is parasitised with monogeneans belonging to the genera Quadriacanthus Paperna, 1961, Paraquadriacanthus Ergens, 1988, Gyrodactylus von Nordmann, 1832 and Macrogyrodactylus Malmberg, 1957 (see Kritsky 1990).

Two species within the genus Macrogyrodactylus have been identified from the catfish $C$. gariepinus in Egypt. These are Macrogyrodactylus clarii Gussev, 1961 from the gills and M. congolensis Prudhoe, 1957 from the skin. These viviparous gyrodactylids multiply rapidly using a combi- nation of different reproductive strategies (reviewed by Cable and Harris 2002) and have been implicated as pathogens (see e.g. Ogawa and Egusa 1980, Cone et al. 1983, Johnsen and Jensen 1986), potentially representing a major cause of fish mortality in a wide variety of economically important aquaculture systems (Amatyakul 1972, Obiekezie and Taege 1991, Dezfuli et al. 2007). A related gyrodactylid Macrogyrodactylus polypteri Malmberg, 1957 does not appear to significantly affect wild fish populations, but within aquaria it can multiply excessively causing death of its host, Polypterus senegalus Cuvier, 1829 (see Khalil 1964, Saoud and Mageed 1969).

Studies on the pathology caused by monogenean parasites are limited (e.g. Aly et al. 1995a,b, El-Seify et al. 1998, El-Naggar et al. 2001, Reda and El-Naggar 2003); in fact ultrastructural studies on the histopathology of helminth parasites of fishes are rare (see review by Rohde 1984, Dezfuli et al. 2007, Abdelmonem et al. 2010). At the light microscope level, Arafa et al. (2009) studied the mode 
of attachment of $M$. clarii and histopathological effects on the host gills. The present study builds on this work using scanning and transmission electron microscopy to investigate further the histopathological impact of $M$. clarii.

\section{MATERIALS AND METHODS}

Specimens of the Nile catfish Clarias gariepinus were caught from the River Nile near Mansoura City, Daqahlia Province, Egypt in 2003 and transported alive to the Faculty of Sciences, Mansoura University. Here, fish were maintained for a few days in an aquarium containing aerated river water at room temperature $\left(25 \pm 5^{\circ} \mathrm{C}\right)$ with natural daylight. The catfish $(\mathrm{n}=50)$ were killed by pithing and severing the spinal cord before the gills were removed, placed in dishes containing filtered river water and then screened for Macrogyrodactylus clarii using a dissecting microscope. The prevalence was $20 \%$ with a mean intensity of 3 and a range of $1-5$ parasites/ infected fish.

Primary gill lamellae with attached specimens of M. clarii and primary gill lamella to which $M$. clarii had been attached were prepared for scanning electron microscopy (SEM) according to Arafa et al. (2003). They were washed several times in distilled water and fixed for about $30 \mathrm{~min}$ at $4{ }^{\circ} \mathrm{C}$ in $1 \%$ osmium tetroxide in $0.1 \mathrm{M}$ sodium cacodylate- $\mathrm{HCl}$ buffered to $\mathrm{pH}$ 7.3. The specimens were washed for $1 \mathrm{~h}$ in several changes of cold buffer $(0.1 \mathrm{M}$ sodium cacodylate containing 3\% sucrose and $0.1 \mathrm{M} \mathrm{CaCl}_{2}$ ). Post-fixation for $2 \mathrm{~h}$ was conducted using $2.5 \%$ glutaraldehyde buffered to $\mathrm{pH} 7.3$ before overnight washing in the same buffer and then dehydration using an ascending series of acetone solutions. Critical point drying was performed using a polaron critical point drying unit with carbon dioxide as the transition fluid. The specimens were then coated with gold and examined with a JEOL STEM electron microscope.

For transmission electron microscopy (TEM), five primary gill lamellae with attached parasites were washed in distilled water and then fixed in $2.5 \%$ glutaraldehyde buffered to $\mathrm{pH} 7.3$ with 0.1 $\mathrm{M}$ sodium cacodylate- $\mathrm{HCl}$ buffer at $4{ }^{\circ} \mathrm{C}$ for $2 \mathrm{~h}$. They were then washed for at least $1 \mathrm{~h}$ in several changes of cold buffer $(0.1 \mathrm{M}$ sodium cacodylate- $\mathrm{HCl}$ containing $3 \%$ sucrose and $0.1 \mathrm{M} \mathrm{CaCl}_{2}$ ), post-fixed in $1 \%$ osmium tetroxide in sodium cacodylate buffer at $4^{\circ} \mathrm{C}$ for $1 \mathrm{~h}$, washed overnight in the same buffer, then dehydrated using an ascending series of ethanol solutions before transfer to a $1: 1$ mixture of propylene oxide and Spurr resin. Specimens were transferred into gelatin capsules containing pure resin. The capsules were placed in an oven overnight at $60^{\circ} \mathrm{C}$. Ultrathin sections were cut at 70-90 nm using an LKB NOVA ultramicrotome and glass knives. The sections were mounted on single-hole and 75 mesh coated grids and stained in a solution of 1-2\% aqueous or alcoholic uranyl acetate for about 30 min followed by Reynolds 2-3\% lead citrate for about $5 \mathrm{~min}$. The sections were examined using a JEOL 100SX transmission electron microscope operating at $80 \mathrm{kV}$.

\section{RESULTS}

The monogenean gill parasite Macrogyrodactylus clarii consists of an anterior body proper and a posterior cupshaped attachment organ (haptor). The haptor has four muscular flaps, one anterior, two lateral and one posterior (Fig. 1). In addition, the haptor accommodates sclerites, namely hamuli, dorsal and ventral bars, accessory sclerites and 16 marginal hooklets (Fig. 1). Two of the marginal hooklets are located one on each of two projections be-

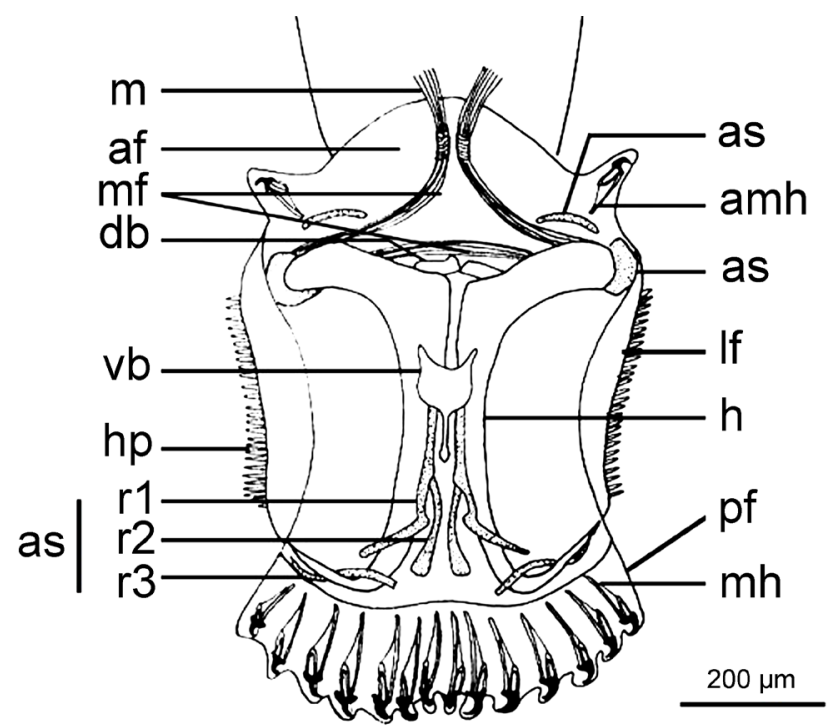

Fig. 1. Diagramatic representation of the haptor of Macrogyrodactylus clarii Gussev, 1961 from Clarias gariepinus (Burchell). Abbreviations: af - anterior flap; amh - anterolateral marginal hooklet; as - accessory sclerites (including $\mathrm{r} 1, \mathrm{r} 2, \mathrm{r} 3$ ); $\mathrm{db}$ - dorsal bar; $\mathrm{h}$ - hamulus; hp - haptoral papillae; lf - lateral flap; $\mathrm{m}$ - extrinsic muscle; $\mathrm{mf}$ - muscle fibres; $\mathrm{mh}$ - marginal hooklet; $\mathrm{pf}$ - posterior flap; vb - ventral bar.

tween the anterior and lateral flaps, while 14 marginal hooklets are located in the posterior flap (Fig. 1). Each of the two lateral flaps is provided with a row of tegumental papillae (Fig. 1). For more anatomical details of $M$. clarii see El-Naggar and Serag (1987).

The morphology of uninfected gills of the catfish Clarias gariepinus resembles that described for other teleost fish species (Wilson and Laurent 2002, Kearn 2004, Arafa et al. 2009, Senger et al. 2011, Elsheikh 2013). Each gill consists of a gill arch from which arise two rows of primary gill lamellae (gill filaments). Each primary gill lamella carries two rows of closely spaced secondary gill lamellae, which project in opposite directions from the two flat surfaces of the primary lamella. The covering epithelium of the secondary gill lamellae consists of thin layers of cells enclosing blood spaces separated by pillar cells.

SEM revealed that, in most cases, the parasites attach their haptor to the lateral flat edge of the primary gill lamellae (free from secondary gill lamellae) by inserting the points of hamuli deeply into the gill tissues, while the anterior, posterior and lateral muscular flaps of the haptor are pressed closely to the gill tissue (Fig. 2). In a few cases, the parasite attaches its posterior edge of the haptor to the lateral edge of the primary gill lamella and extends the remaining part of the haptor to enclose an area equivalent to 4-5 secondary gill lamellae. There is no evidence that the marginal hooklets are inserted into the gill tissue (Fig. 2). Also, no parasites were seen attached either to the gill arch or to the gill rakers.

The 'footprint' left by the parasite's haptor on the host (Fig. 3) is elevated above the general gill surface and bordered by cleft at the site of attachment of the anterior flap (Figs. 3-5). At the anterolateral region of the footprint, the lateral haptoral flaps create a wide shallow depression 

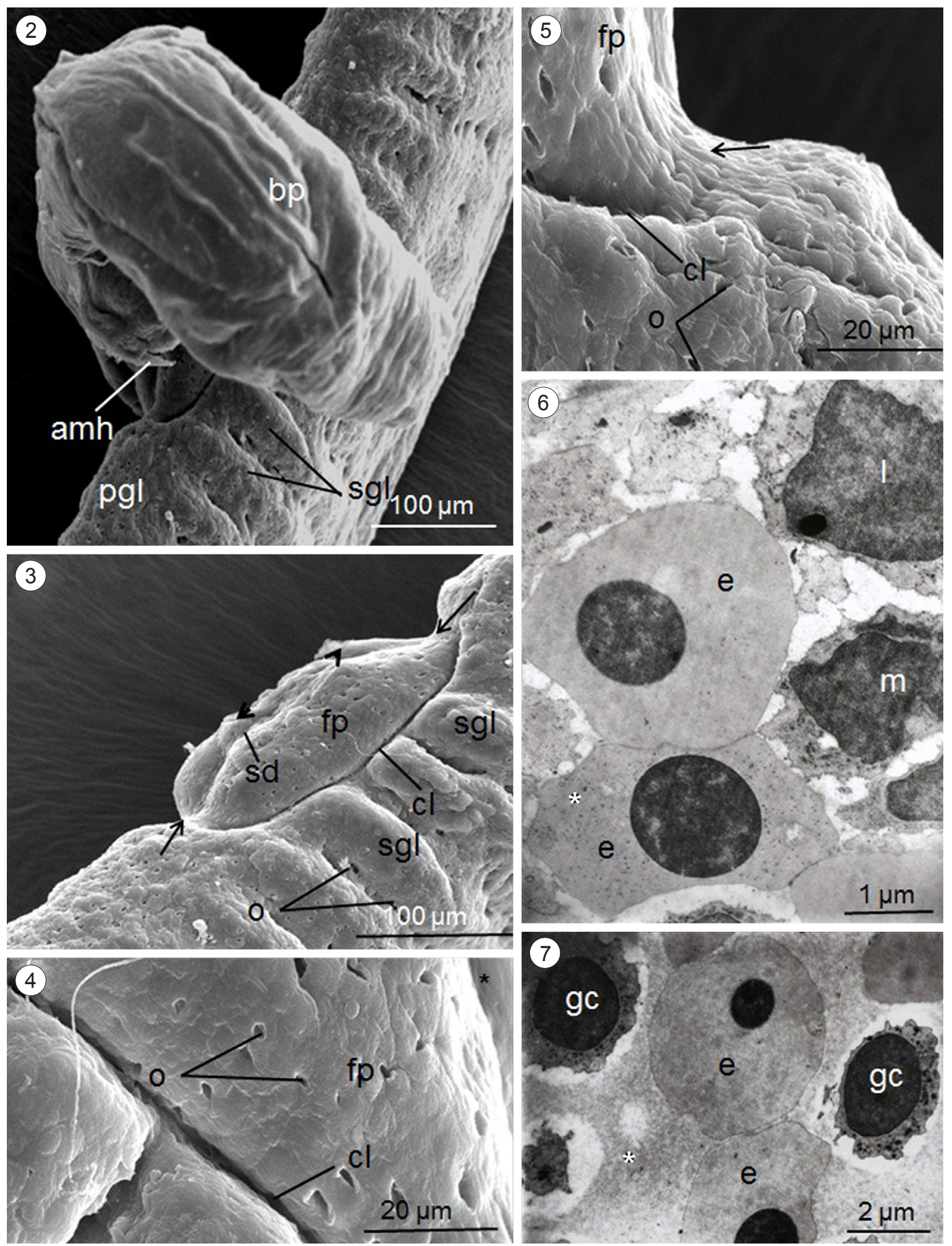

Figs. 2-5. Scanning electron micrographs showing Macrogyrodactylus clarii Gussev, 1961 from Clarias gariepinus (Burchell) attached to the primary gill lamella (gill filament) and the footprint of the haptor. Fig. 2. Attachment to the primary gill lamella; note that the anterolateral marginal hooklet is not inserted into the gill tissue. Fig. 3. The footprint of the haptor showing cleft created by the anterior flap and shallow depression on the surface of the elevated part; note the compression created by the lateral flap (arrows) and the ruptured tissue on the surface (arrow heads). Fig. 4. Magnified part of the footprint of the haptor showing large and small openings on the host surface. Fig. 5. Magnified part of the footprint of the haptor showing openings on the surface, cleft created by the anterior flap and shallow depression created by the lateral flap (arrow). Figs. 6, 7. Transmission electron micrographs through attachment site of $M$. clarii. Fig. 6. Erythrocytes and agranular leucocytes, probably lymphocyte and monocyte; note the presence of electron-dense particles $(*)$ in erythrocyte cytoplasm. Fig. 7. Erythrocytes and granular leucocytes; note the presence of erythrocyte cytoplasmic matrix $(*)$ in the lumen of blood space. Abbreviations: amh - anterolateral marginal hooklet; bp - body proper; cl - cleft; e - erythrocytes; fp - footprint of the haptor; gc - granular leucocytes; 1 - lymphocyte; $\mathrm{m}$ - monocyte; o - opening; pgl - primary gill lamella; $\mathrm{sd}$ - shallow depression; sgl - secondary gill lamellae. 

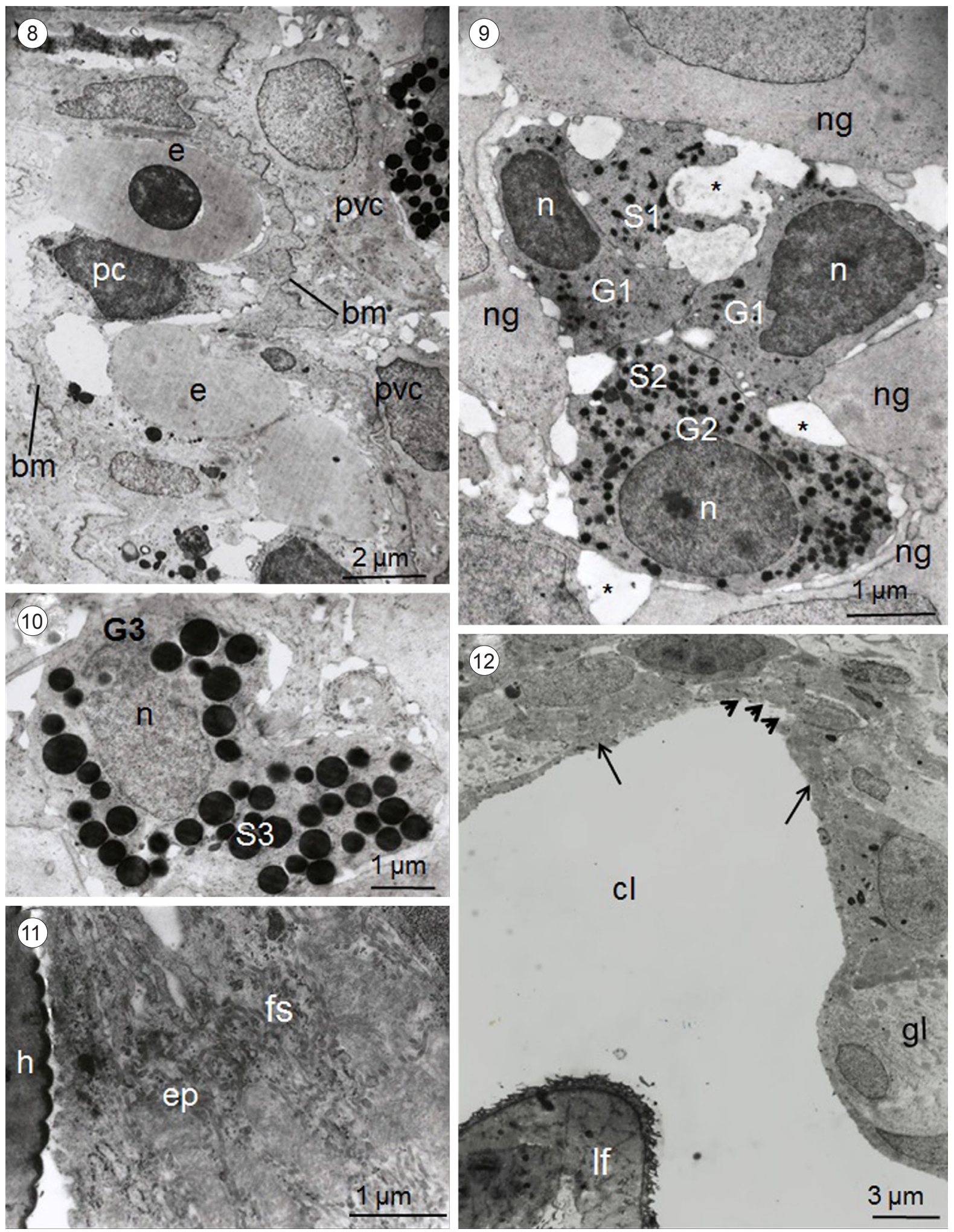

Figs. 8-12. Transmission electron micrographs through attachment site of Macrogyrodactylus clarii Gussev, 1961 from Clarias gariepinus (Burchell). Fig. 8. Blood space in the secondary gill lamella, held open by pillar cells and surrounded by pavement cells, note that these blood spaces are bounded by a thick basement membrane. Fig. 9. Secondary gill lamella showing non-granular epithelial cells surrounding three gland cells; note the presence of two types of gland cell: G1 cell with irregularly-shaped nucleus and small spherical granules and G2 cell with large rounded nucleus and medium-sized spherical granules; also note the presence of intercellular spaces between cells (*). Fig. 10. Gland cell with larger secretory bodies. Fig. 11. Part of the hamulus blade inserted in adjacent epithelium of the primary gill lamella; note the tubular fibrillar structures in the adjacent cytoplasm. Fig. 12. Cleft created by the lateral flap and adjacent surface epithelium of the gills; note the compressed cells (arrows) and ruptured cells (arrow heads). Abbreviations: bm - basement membrane; cl - cleft; e - erythrocyte; ep - epithelium; fs - fibrillar structures; G1-3 - gland cell; gl - host gland cell; h - hamulus blade; lf - lateral flap; $\mathrm{n}$ - nucleus; ng - non-granular epithelial cells; pc - pillar cells; pvc - pavement cells; S1 - small spherical granules; S2 - medium-sized spherical granules; S3 - larger secretory bodies. 

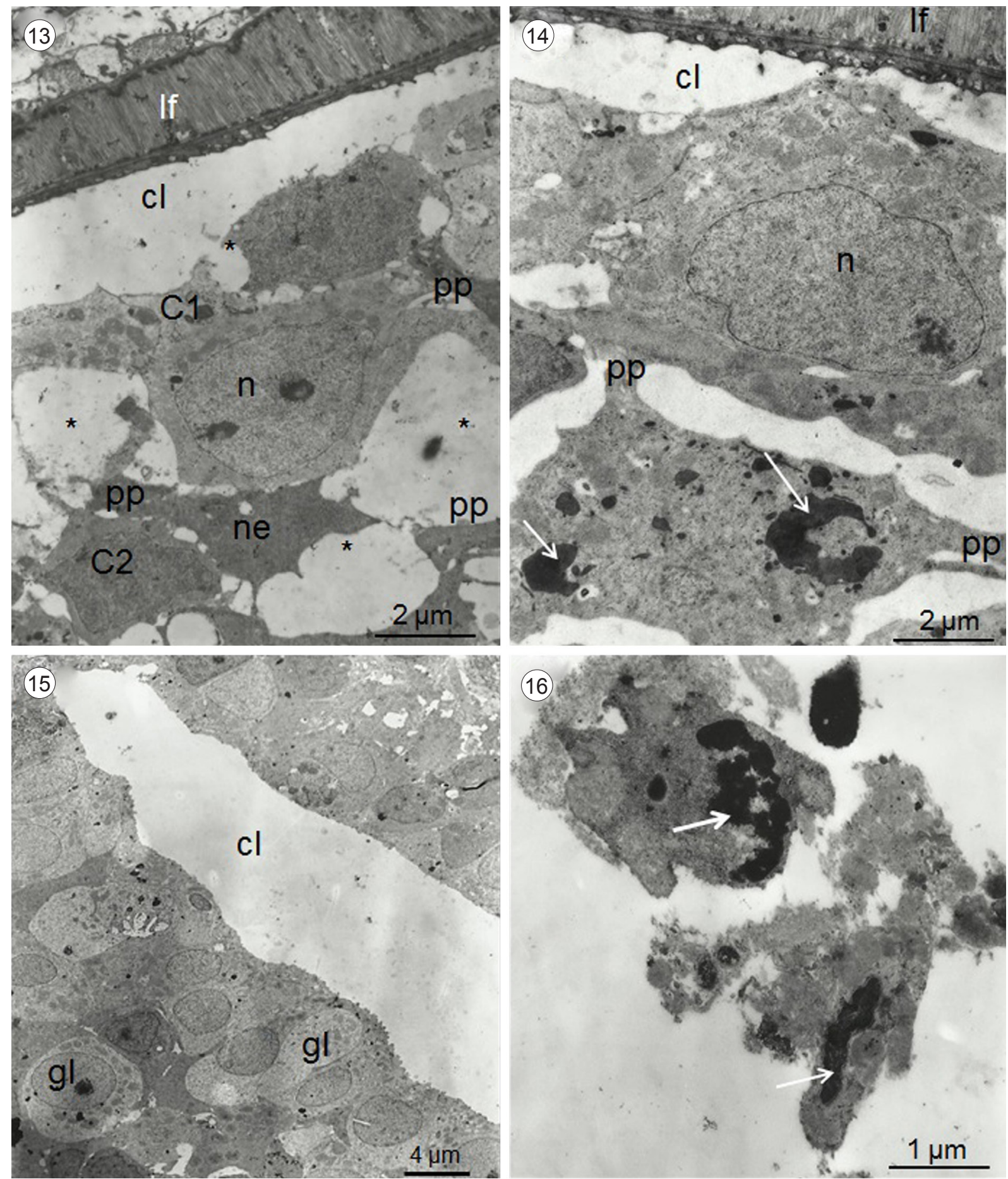

Figs. 13-16. Transmission electron micrographs through attachment site of Macrogyrodactylus clarii Gussev, 1961 from Clarias gariepinus (Burchell). Fig. 13. Cleft created by the lateral flap close to host cells; note the large intercellular spaces $(*)$ and the necrotic tissue. Fig. 14. Cleft created by the lateral flap and widely spaced host cells; note one cell with intact nucleus and the other cell with pyknotic nucleus (arrows). Fig. 15. Host surface epithelial layer close to the cleft produced by the lateral flap; note the accumulation of presumptive host gland cells near the surface. Fig. 16. Detached damaged host epithelial cells close to the tegument of the parasite; note the condensed heterochromatin in the cytoplasm (arrows). Abbreviations: C1, C2 - host cells; cl - cleft; gl - gland cells; lf - lateral flap; $\mathrm{n}$ - nucleus; ne - necrotic tissue; $\mathrm{pp}$ - pseudopodium-like processes.

(Figs. 3, 5). In this depression, the gill tissues appear to be greatly compressed (Fig. 4). Another shallow depression, which may represent an imprint produced by a group of transverse muscles in the haptor, is seen on the surface of the elevated region of the footprint (Fig. 3). The surface of the elevated portion of the gill tissue appears similar to the surrounding tissue, but the upper surface of the anterior region (the site of attachment of the anterior flap of the haptor) was undamaged (Fig. 3). The general surface of the secondary gill lamellae and the footprint created by the haptor of M. clarii in the primary gill lamella are similar in having many small and large presumptive openings of host mucous 

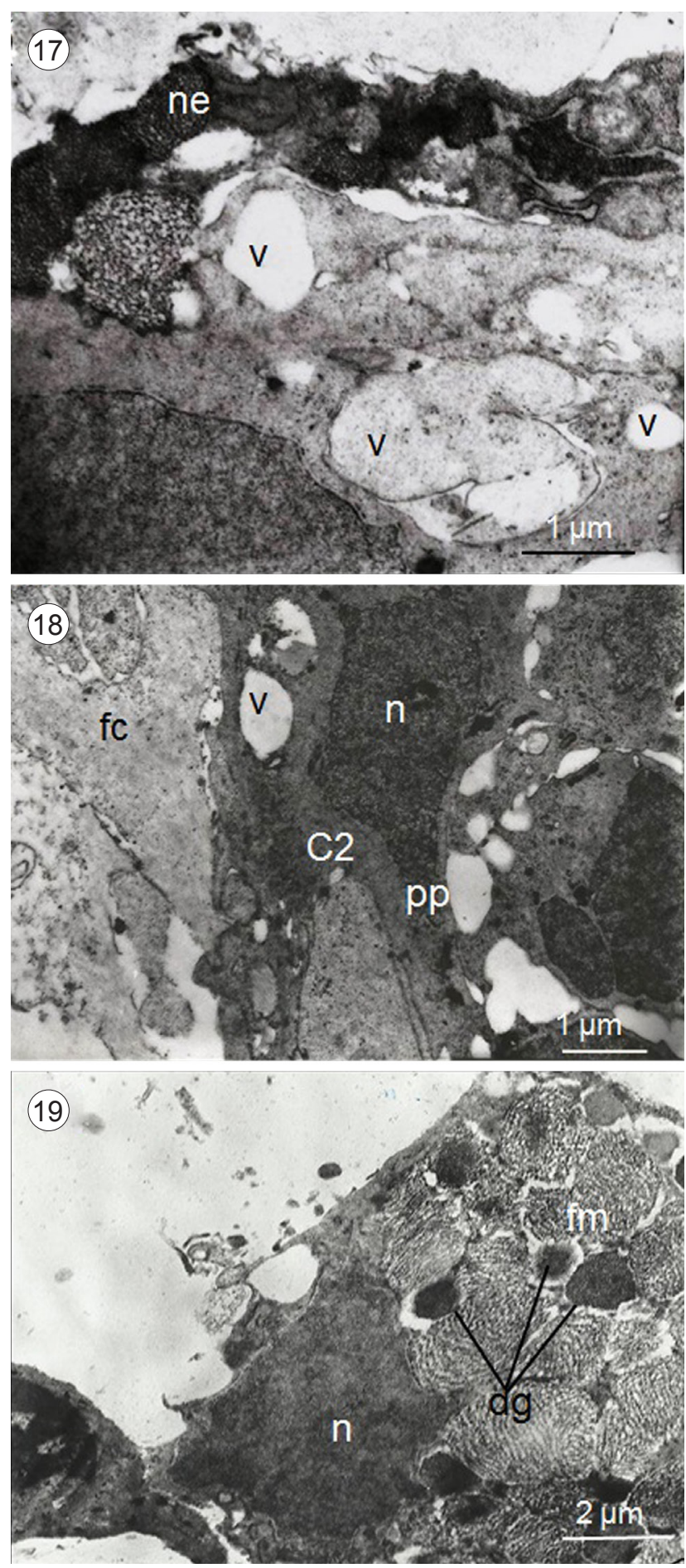

Figs. 17-19. Transmission electron micrographs through attachment site of Macrogyrodactylus clarii Gussev, 1961 from Clarias gariepinus (Burchell). Fig. 17. Host epithelial cell with many small and large vacuoles and necrotic tissue. Fig. 18. Host epithelial cell with fibrotic cytoplasm; the $\mathrm{C} 2$ cell has an intact nucleus and pseudopodium-like processes. Fig. 19. Detached host cell with cytoplasm packed with fibrotic masses and some electron dense granules. Abbreviations: $\mathrm{C} 2$ - host cells; dg - dense granules; fc - fibrotic cytoplasm; fm - fibrotic masses; $\mathrm{n}$ - nucleus; ne - necrotic tissue; $\mathrm{v}$ - vacuole; $\mathrm{pp}$ - pseudopodium-like processes.

gland cells (Figs. 3, 4). A few larger openings were also detected on the surface of the primary gill lamella between the secondary gill lamellae (Fig. 3).
TEM sections of secondary gill lamellae of $M$. clarii revealed host blood spaces containing erythrocytes and both granular and agranular leucocytes (Figs. 6-8). Many erythrocytes were packed and compressed with no regular outline (Fig. 6) while others were free, spherical or oval (Fig. 8). Erythrocytes had a centrally-located nucleus with highly electron-dense chromatin (Figs. 6-8). In most erythrocytes, the cytoplasm is filled with homogeneous moderately electron-dense material but a few erythrocytes contain distinct, highly electron-dense particles embedded in the cytoplasm matrix (Fig. 6). In some sections of the blood spaces inside the secondary gill lamellae, erythrocytes appear to have ruptured with their cytoplasm filling the lumen surrounding other blood cells (Fig. 7).

The granular leucocytes, frequently observed in the blood spaces of the secondary gill lamellae, are small $(5-8 \mu \mathrm{m}$ diameter) and oval with an irregular outline, each with a large, eccentric nucleus occupying much of the cytoplasm (Fig. 7). The cytoplasm is filled with electron-dense bodies and a few, small, translucent vesicles. Agranular leucocytes, probably lymphocytes and monocytes, had large nuclei and agranular cytoplasm (Fig. 6). The lymphocytes appear to be slightly smaller than the monocytes, the latter having kidney-shaped nuclei (Fig. 6). The plasma membrane of both granular and agranular leucocytes have cytoplasmic extensions (Figs. 6, 7).

Blood spaces of the secondary gill lamellae are bounded by an endothelium with a thick basement membrane and surrounded by pavement cells, which are flattened with a rounded or elongated nucleus (Fig. 8). Some pavement cells appear vacuolated with intercellular spaces between these cells and adjacent epithelial cells (Fig. 8). Each pillar cell possesses a large nucleus with an irregular outline and cytoplasm containing fine particles, probably glycogen granules (Fig. 8). Some pillar cells display necrotic changes.

At the attachment site of the haptor of $M$. clarii, three types of host gland cell were observed among non-glandular epithelial cells (Figs. 9, 10). The G1 cell has a large oval nucleus with condensed chromatin and an irregular outline (Fig. 9). The cytoplasm contains a moderate number of small, highly electron-dense bodies (S1) (Fig. 9). The G2 cell has a spherical nucleus and cytoplasm filled with numerous medium-sized, nearly spherical, highly electron-dense bodies (S2), many ribosomes and a few mitochondria. The G3 cell possesses an elongated nucleus and cytoplasm packed with large, spherical, highly electron-dense bodies (S3) (Fig. 10). There are intercellular spaces between the G1, G2 and G3 cells and adjacent non-glandular cells (Figs. 9, 10).

TEM revealed that the blades of the hamuli are inserted into gill tissues of the primary gill lamellae (Fig. 11), while there is no evidence of the insertion of the marginal hooklets. The outer surface of each hamulus has a serrated outline (Fig. 11) and adjacent host cells are ruptured and vacuolated. The cytoplasm of these cells loses its integrity and forms numerous short and long, moderately electron-dense tubular and fibrillar structures (Fig. 11). Lateral muscular, haptoral flaps with tegumental papillae are inserted in a deep cleft of the host primary gill lamella. The surface epithelial cells facing the cleft appear to be intact in some 
regions but compressed and ruptured in others (Fig. 12). The nuclei of the compressed cells are elongated and large. Probably mucoid gland cells are close to the cleft (Fig. 12). Adjacent to the cleft produced by the lateral flaps, desquamated epithelium is apparent and two types of cells could be detected: $\mathrm{C} 1$ with moderately electron-dense cytoplasm and C2 with highly electron-dense cytoplasm (Fig. 13). The cytoplasm of $\mathrm{C} 1$ cells contains abundant mitochondria and rough endoplasmic reticulum (Fig. 13). Large intercellular spaces occur between the desquamated host epithelial cells (Fig. 13). Some of these cells have pyknotic nuclei with scattered condensed heterochromatin in the cytoplasm, while the nuclei of the others are normal (Fig. 14). Some of the widely spaced host epithelial cells possess pseudopodium-like cytoplasmic processes (Figs. 13, 14). Necrotic tissue is seen in the region of attachment of the lateral flap (Fig. 13). In some regions very close to the cleft created by the lateral flap, accumulations of spherical and oval putative gland cells were identified (Fig. 15). The cytoplasm of these host cells contains abundant mitochondria and their nuclei are central or peripheral in position with conspicuous nucleoli (Fig. 15).

In TEM sections, the posterior flap of the attached haptor produces a deep cleft in the surface epithelial layers of the host gill. No intact host cell layer was detected and cells facing the cleft produced by the posterior flap are widely spaced. Pseudopodium-like processes and necrotic tissues were also observed at the attachment site close to the cleft. Some damaged cells almost detached from the surface epithelial layer of the host gill tissue were found close to the tegument covering the ventral surface of the haptor. The nuclei of some of these cells have irregular shapes with peripheral condensed heterochromatin, while others appeared pyknotic with condensed heterochromatin in the cytoplasm (Fig. 16).

In the attachment site of the ventral surface of the haptor, necrotic tissue and damaged and intact vacuolated host cells were also detected (Figs. 17, 18). Cells with fibrotic cytoplasm are always associated with these vacuolated cells (Fig. 18). One of the detached host cells had a peripheral irregularly-shaped nucleus with dispersed heterochromatin and cytoplasm packed with dense fibres and some electron-dense granules (Fig. 19).

\section{DISCUSSION}

This is the first ultrastructural study on the histopathological effects of the monogenean Macrogyrodactylus clarii on the gills of the catfish Clarias gariepinus. Previously, Arafa et al. (2009) recorded breakdown of the gill epithelium, epithelial cell necrosis, host cell vacuolation, fusion of the gill lamellae, ruptured blood capillaries, infiltration of erythrocytes and degeneration and fibrosis of the inter-lamellar epithelium of catfish infected with $M$. clarii. In the present study, SEM and TEM revealed surface damage of the host gill tissues, compressed and widely spaced host cells, desquamated surface epithelia adjacent to the lateral flaps of the parasite, vacuolated cells, necrotic tissue and damaged cells with pyknotic nuclei.

Attachment of the haptor of M. clarii was achieved mainly by insertion of the blades of hamuli. No evidence was found to indicate that the marginal hooklets participat- ed in attachment and this is not uncommon in other monogenean species (e.g. Harris 1983, El-Naggar et al. 2001). In contrast, in some other species, marginal hooklets do appear to contribute to attachment (e.g. Lester 1972, Molnár 1972, Cone and Odense 1984, Ramadan et al. 1995). Arafa et al. (2003) reported that some of the 16 marginal hooklets of $M$. congolensis, a congeneric skin monogenean on the same host ( $C$. gariepinus), were superficially inserted into the skin.

Harris (1983) suggested that the marginal hooklets may prevent the hamuli of the oviparous gyrodactylid Oogyrodactylus farlowellae Harris, 1983 from turning about their longitudinal axis and tearing free of the host skin of the catfish Farlowella amazonum Günther. The footprint of the haptor of $M$. clarii appeared to be elevated from the general surface of the host gills and bounded by clefts produced by muscular, anterior, lateral and posterior marginal flaps of the haptor. These observations suggest that $M$. clarii uses suction during haptoral attachment, similar to M. congolensis during attachment to the skin of the host (see Arafa et al. 2003).

In terms of the host response against $M$. clarii, leucocytes in the blood spaces and among the epithelial cells covering the host's gills at the site of attachment probably function as phagocytes. Adjacent to the lateral flaps, host cells were closely packed and compressed with elongated nuclei. The pressure created by the haptoral flaps creates large intercellular spaces and some host cells appear to detach completely from the surface epithelial layer of the gill. Large intercellular spaces are a common pathogenic effect reported for other helminth parasites. For example, Perera (1992) detected large intercellular spaces between the epithelial cells of the capsule formed on the gills of Scomber australasicus Cuvier around didymozoid digenean parasites. Desquamation of gill epithelial cells of the European eel Anguilla anguilla Linnaeus infected with monogeneans was recorded by Abdelmonem et al. (2010). In the infected gill regions of $C$. gariepinus, epithelial cells with pseudopodium-like processes were also detected. Similar cells were detected in the gill epithelium of $S$. australasicus around a digenean (Perera 1992). Cells may migrate to compensate for stretching of the epithelium, with cell detachment and pseudopodium-like processes potentially facilitating this process (Perera 1992).

Resistance against monogeneans is partly associated with host mucus secretion (Evans and Gratzek 1989), which may form a protective sheath against the invasion of ectoparasites The present study revealed the presence of abundant unicellular host glands, probably host mucous cells in the surface epithelial layer adjacent to the attachment site of the lateral flap of the haptor. Accumulation of these cells may represent one of the host responses against infection with $M$. clarii. Concentration of mucoid cells at the site of infection was also recorded in the gill tissues of grass carp infected with the monogenean Dactylogyrus lamellatus Achmerow, 1952 (see Molnár 1972), but Perera (1992) recorded no obvious change in the number of mucous cells as a result of infection of $S$. australasicus with didymozoid trematodes. In contrast, a decrease in mucous 
cells in the skin epidermis and gills of salmonid fishes infected with Ichthyobodo necator Henneguy, 1883 was reported by Robertson et al. (1981), Pottinger et al. (1984), Roubal et al. (1987) and Wells and Cone (1990).

Host cells with fibrotic cytoplasm were detected in the surface epithelial layer of the gill tissue of C. gariepinus. Perera $(1992,1994)$ detected electron-dense filamentous bands in the cytoplasm of the epithelial cells in the capsule wall formed around didymozoid parasites on the gills of S. australasicus. Presence of fibres in the cytoplasm of the host cells may be indicative of host responses against infection. These cytoplasmic filaments may give additional strength to the host cells and the surface layer subject to pressure produced by the parasites. Other components of host resistance against monogeneans reported previously include complement factors, immunoglobulins, peptides, lysosomes and various carbohydrates (St. Louis-Cormier et al. 1984, Sakai 1992, Yano 1996, Harris et al. 1997, Buchmann and Bresciani 1998).

Gyrodactylids are implicated as pathogens of both freshwater and marine fishes (Sterud et al. 1998). Paladini et al. (2009), for example, reported 2-10\% mortality among farmed populations of the seabream Sparus aurata Linnaeus heavily infected with Gyrodactylus orecchiae Paladini, Cable, Fioravanti, Faria, Di Cave et Shinn, 2009. Although the mean intensity of $M$. clarii encountered in the present study was relatively low, it will be important to determine the impact of this gyrodactylid on C. gariepinus stocks reared under intensive aquaculture conditions.

Acknowledgements. The work was funded by a Royal Society Developing World Visit Research Grant to MME. JC was funded by the Welsh Government and Higher Education Funding Council for Wales through the AquaWales Sêr Cymru National Research Network for Low Carbon, Energy and Environment.

\section{REFERENCES}

Abdelmonem A.A., Metwally M.M., Hussein H.S. 2010: Gross and microscopic pathological changes associated with parasitic infection in European eel (Anguilla anguilla Linnaeus, 1758). Parasitol Res. 106: 463-469.

Ali M.Z. 2001: Dietary protein and energy interactions in African catfish Clarias gariepinus (Burchell, 1822). PhD Thesis, Institute of Aquaculture, University of Stirling, Stirling, $217 \mathrm{pp}$.

Aly S., Mayberry L., El-Melegy A., El-Gwady H. 1995a: Pathological studies on parasitic infections in Tilapia nilotica. Egypt. J. Comp. Pathol. Clinic. Pathol. 8: 147-157.

Aly S., Mayberry L., El-Melegy A., El-Gwady H. 1995b: Pathological studies on parasitic infections in common carp. Egypt. J. Comp. Pathol. Clinic. Pathol. 8: 123-130.

Amatyakul C. 1972: Parasites of pond-raised Clarias in Thailand. FAO Aquacult. Bull. 5: 16-17.

Arafa S.Z., El-Naggar M.M., El-Abbassy S.A. 2009: Mode of attachment and histopathological effects of Macrogyrodactylus clarii, a monogenean gill parasite of the catfish Clarias gariepinus, with a report on host response. Acta Parasitol. 54: 103-112.

Arafa S.Z., El-Naggar M.M., Kearn G.C. 2003: Scanning electron microscope observations on the monogenean skin parasite Macrogyrodactylus congolensis (Prudhoe, 1957) Yamaguti, 1963. Acta Parasitol. 48: 163-171.

Bishai H.M., Khalil M.T. 1997: Freshwater Fishes of Egypt. Publication of the National Biodiversity Unit No. 9, Department of Natural Protectorate, Egyptian Environmental Affairs Agency, Cario, $229 \mathrm{pp}$.

Buchmann K., Bresciani J. 1998: Microenvironment of Gyrodactylus derjavini on rainbow trout Oncorhynchus mykiss: association between mucous cell density in skin and site selection. Parasitol. Res. 84: 17-24.

Cable J., Harris P.D. 2002: Gyrodactylid developmental biology: historical review, current status and future trends. Int. J. Parasitol. 32 : 255-280.

Cone D.K., Beverley-Burton M., Wiles M., McDonald T.E. 1983: The taxonomy of Gyrodactylus (Monogenea) parasitizing certain salmonid fishes of North America, with a description of G. nerkae n. sp. Can. J. Zool. 61: 2587-2597.

Cone D.K., Odense P.H. 1984: Pathology of five species of $G y$ rodactylus von Nordmann, 1832 (Monogenea). Can. J. Zool. 62: 1084-1088.

Dezfuli B.S., Giari L., Simoni E., Menegatti R., Shinn A.P., MAnerA M. 2007: Gill histopathology of cultured European sea bass, Dicentrarchus labrax (L.), infected with Diplectanum aequans (Wagener 1857) Diesing 1958 (Diplectanidae: Monogenea). Parasitol. Res. 100: 707-713.
El-Naggar M.M., Hagras A.E., Ogawa K., Hussein A.B. El-Naggar A.M. 2001: Attachment of Cichlidogyrus monogenean species to the gills of the Nile fish Oreochromis niloticus and their local pathological impact on them. J. Egypt. Ger. Soc. Zool. 35: 143-155.

El-Naggar M.M., Serag H.M. 1987: Redescription of Macrogyrodactylus clarii Gussev 1961, a monogenean gill parasite of Clarias lazera in Egypt. Arab. Gulf J. Sci. Res. Agric. Biol. Sci. 5: 257-271.

El-Seify M., Soliman M.K., Mahfouz N.B. 1998: Effect of parasitism on certain immunological parameters of cultured fishes. Egypt. J. Aquat. Biol. Fish. 2: 379-405.

Elsheikn E.H. 2013: Scanning electron microscopic studies of gill arches and rakers in relation to feeding habits of some fresh water fishes. J. Basic Appl. Zool. 66: 121-130.

Evans D.L., GratzeK J.B. 1989: Immune defense mechanisms in fish protozoan and helminth infections. Am. Zool. 29: 409-418.

FAO 1997: Aquaculture production, 1986-1995, FAO Fish Circ. No 815 (FIDID/815-Rev.9), FAO, Italy.

HARRIS P.D. 1983: The morphology and life-cycle of the oviparous Gyrodactylus farlowellae gen. et sp. nov. (Monogenea: Gyrodactylidae). Parasitology 87: 405-420.

Harris P.D., Cable J., Tinsley R.C. 1997: Detection of sperms within Gyrodactylus (Platyhelminthes, Monogenea) tissues using fluorescence and transmission electron microscopy. Parasitol. Res. 83: 533-538.

Hogendoorm H. 1983: The African catfish, (Clarias lazera C. \& V., 1840) a new species for aquaculture. PhD thesis, Wageningen Agricultural University, Wageningen, $135 \mathrm{pp}$.

Johnsen B.O., Jensen A. 1986: Infestations of Atlantic salmon, Salmo salar, by Gyrodactylus salaris in Norwegian rivers. J. Fish Biol. 29: 233-241.

Kearn G.C. 2004: Leeches, Lice and Lampreys. A Natural History of Skin and Gill Parasites of Fishes. Springer, Dordrecht, 432 pp.

KHALIL L. 1964: On the biology of Macrogyrodactylus polypteri Malmberg, 1956, a monogenetic trematode on Polypterus senegalus in the Sudan. J. Helminthol. 38: 219-222.

Kritsky D.C. 1990: Synonymy of Paraquadriacanthus Ergens, 1988 (Monogenea: Dactylogyridae) and their type species. Folia Parasitol. 37: 76.

LeSter R.J.G. 1972: Attachment of Gyrodactylus to Gasterosteus and host response. J. Parasitol. 58: 717-772.

Molnár K. 1972: Studies on gill parasitosis of the grass carp (Ctenopharyngodon idella) caused by Dactylogyrus lamellatus Achmerov, 1952. IV. Histopathological changes. Acta Vet. Acad. Sci. Hung. 22: 9-24. 
Obiekezie A.I., TAege M. 1991: Mortality in hatchery reared fry of the African catfish Clarias gariepinus (Burchell) caused by Gyrodactylus groschafti Ergens, 1973. Bull. Eur. Ass. Fish Pathol. 11: 82-85.

OGawa K., Egusa S. 1980: Gyrodactylus infections of cultured eels (Anguilla japonica and A. anguilla) in Japan. Fish Pathol. 15: 95-99.

Paladini G., Cable J., Fioravanti M.L., Faria P.J., Cave D.D. 2009: Gyrodactylus orecchiae sp. n. (Monogenea: Gyrodactylidae) from farmed populations of gilthead seabream (Sparus aurata) in the Adriatic Sea. Folia Parasitol. 56: 21-28.

Perera K.M.L. 1992: Ultrastructure of the primary gill lamellae of Scomber australasicus infected by a didymozoid parasite. Dis. Aquat. Organ. 13: 111-121.

Perera K.M.L. 1994: Light and electron microscopic study of the pathology of a species of didymozoid (Trematoda, Digenea) infecting the gill arches of Scomber australasicus (Teleostei, Scombridae). Dis. Aquat. Organ. 18: 119-127.

Pottinger T.G., Pickering A.D., Biackstock N. 1984: Ectoparasite-induced changes in epidermal mucification of the brown trout Salmo trutta L. J. Fish Biol. 25: 123-126.

Ramadan N.F., El-Banhawy M.A., Abdel Salam M.A. 1995: Parasitological investigation on two monogenetic trematodes and their pathological impact on the grass carp Ctenopharyngodon idella in Egypt. J. Egypt. Germ. Soc. Zool. 17: 17-37.

Reda E.S., EL-NagGar A.M. 2003: Mode of attachment of the monogenean Protoancylodiscoides mansourensis El-Naggar, 1987 to gills of the longfin catfish Chrysichthys auratus, with reference to host-parasite interface, Egypt. J. Aquat. Biol. Fish. 7: 359-380.

Robertson D.A., Roberts R.J., Bullock A.M. 1981: Pathogenesis and autoradiographic studies of the epidermis of the salmonids infested with Ichthyobodo necator (Henneguy, 1883). J. Fish Dis. 4: 113-125.
Rohde K. 1984: Diseases caused by metazoans: helminths. Dis. Mar. Animal 4: 193-320.

Roubal F.R., Bullock A.M., Robertson D.A., Roberts R.J. 1987: Ultrastructural aspects of infestation by Ichthyobodo necator (Henneguy, 1883) on the skin and gills of the salmonids Salmo salar L. and Salmo gairdneri Richardson. J. Fish. Dis. 10: 181-192.

SAKAI D.K. 1992: Repertoire of complement in immunological defense mechanisms of fish. Ann. Rev. Fish Dis. 2: 223-247.

SAOUd M.F., Mageed A. 1969: Host parasite relationship of $\mathrm{Macr}$ ogyrodactylus polypteri (Trematoda: Monogenea) in some fishes of the Sudan. Curr. Sci. 38: 209-210.

Senger M., Yadav L., Gopesh A. 2011: Fine structure of the gill epithelia of the African catfish Clarias gariepinus (Bur.) ESEM and TEM study of principal cell types. Nat. Acad. Sci. Let. 34: 285-291.

St. Louis-Cormier E.A., Osterland C.K., Anderson P.D. 1984: Evidence for a cutaneous secretory immune system in rainbow trout (Salmo gairdneri). Develop. Comp. Immunol. 8: 715-780.

Sterud E., Harris P.H., Bakke T.A., 1998. The influence of $G y$ rodactylus salaris Malmberg, 1957 (Monogenea) on the epidermis of Atlantic salmon, Salmo salar L., and brook trout, Salvelinus fontinalis (Mitchill), experimental studies. J. Fish Dis. 21: 257-263.

Wells P.R., Cone D.K. 1990: Experimental studies on the effect of Gyrodactylus colemanensis and G. salmonis (Monogenea) on the density of the mucous cells in the epidermis of fry of Oncorhynchus mykiss. J. Fish Biol. 37: 5995-5603.

Wilson J.M., LAUREnT P. 2002: Fish gill morphology: inside out. J. Exp. Zool. 293: 192-213.

YANO T. 1996: The nonspecific immune system: humoral defense. In: G. Iwama and T. Nakanishi (Eds.), The Fish Immune System: Organism, Pathogen and Environment. Academic Press, New York, pp. 106-157.

Cite this article as: El-Naggar M.M., Cable J., Arafa S.Z., El-Abbassy S.A., Kearn G.C. 2016: Scanning and transmission electron microscopy of the histopathological impact of Macrogyrodactylus clarii (Monogenea: Gyrodactylidae) on the gills of catfish, Clarias gariepinus. Folia Parasitol. 63: 017. 